\title{
Enzymes of the 3-Oxoadipate Pathway in Fungi: A Serological Study of 3-Carboxymuconate Cyclase (Lactonizing Enzyme) in Fungi and its Possible Taxonomic Significance
}

\author{
By K. A. COOK* AND R. B. CAIN \\ Biological Laboratories, University of Kent, Canterbury, Kent CT2 $7 \mathrm{NJ}$
}

(Received I5 April 1977)

The immunoglobulin fraction of antiserum prepared against a homogeneous preparation of 3-carboxymuconate cyclase from Aspergillus niger L6 was used to study the serological relatedness of the enzyme in crude extracts of other fungi. Immunodiffusion and immunoelectrophoresis experiments confirmed the homogeneity of the pure $A$. niger L6 cyclase, its serological identity with the same enzyme in other strains of $A$. niger and the complete absence of any cross-reaction with the analogous 3-carboxymuconate cycloisomerase from Pseudomonas putida and Nocardia opaca. Extensive cross-reactions were observed with the cyclases from other species of Aspergillus and Penicillium. When such cross-reactions were examined quantitatively by the precipitin technique, several genera believed to be taxonomically related to Aspergillus and Penicillium on morphological grounds showed crossreacting cyclases. Within the genera there was a broad correlation of serological relationships with morphological subdivisions. These correlations were considerably better than can be achieved by determinations of DNA base compositions because most of the genera examined have GC ratios of 50 to $55 \mathrm{~mol} \%$. Crude extracts of two taxonomically unrelated Basidiomycetes showed no serological relatedness to the antisera.

\section{INTRODUCTION}

The 3-oxoadipate pathway is utilized by bacteria and fungi for the transformation of catechol, protocatechuate and their respective precursors to succinate and acetyl-CoA. The biochemistry of the pathway is similar in both groups of micro-organisms, although in all fungi the subsequent metabolism of the ring cleavage product, 3-carboxymuconate, proceeds through 3-carboxymuconolactone (Gross, Gafford \& Tatum, 1956; Cain, Bilton \& Darrah, 1968a) rather than through the 4 -substituted isomer as in bacteria (Stanier \& Ornston, 1973).

The enzymes effecting lactonization of 3 -carboxymuconate, which are called cycloisomerases in bacteria and cyclases in fungi to distinguish their mode of lactonization (I.U.P.A.C.-I.U.B. Commission on Biochemical Nomenclature, 1972), have been purified from Pseudomonas putida (Patel, Meagher \& Ornston, 1973) and Aspergillus niger (Thatcher $\&$ Cain, 1974a); they differ substantially in their amino-acid composition and quaternary structure and in many kinetic properties. The majority of fungi produce 3-carboxymuconate cyclases with essentially similar kinetic properties though the enzyme in Basidiomycetes disaggregates rather easily from the normal multimeric form (R. B. Cain, A. Columbi \& B. A. Halsall, unpublished work). To find out if this similarity in catalytic properties extended to the enzyme structure, we utilized an antiserum, prepared against a homogeneous

* Present address: Microbiology Division, Shell Biosciences Laboratory, Shell Research Limited, Sittingbourne, Kent ME9 8AG. 
preparation of 3-carboxymuconate cyclase from $A$. niger L6 (Thatcher \& Cain, I974a), to examine the extent of antigenic homology of this enzyme in fungi capable of degrading aromatic compounds and to confirm the anticipated serological dissimilarity of the fungal and bacterial enzymes.

\section{METHODS}

Organisms. Aspergillus niger L6, Penicillium puberulum B3 and Penicillium crustosum P6 (CMI19I672) were isolated from soil and Schizophyllum commune from rotting wood by Dr B. Halsall (Cain et al., 1968a). The two penicillia were identified by Dr A. H. S. Onions (Commonwealth Mycological Institute, Kew, Surrey). Other strains of $A$. niger used were CMI4555I, one designated 'Newcastle' (from Dr C. H. Dickinson, Department of Plant Biology, University of Newcastle upon Tyne) and one designated 'Birkbeck' (from Dr Jane North, Department of Biological Sciences, City of London Polytechnic, London EI 7 NT). Strain PL30 was a temperature-sensitive mutant derived from $A$. niger $\mathrm{L} 6$ by treatment with $\beta$-propiolactone (E. A. Ahlquist, unpublished results). It produced a catalytically active 3-carboxymuconate cyclase when grown at $25{ }^{\circ} \mathrm{C}$ or below but not at $30{ }^{\circ} \mathrm{C}$. Rhodotorula mucilaginosa and Aureobasidium pullulans were isolated as aerial contaminants on $p$-hydroxybenzoate medium (Cain et al., I968a) and identified by the Brewing Industry Foundation, Nutfield, Surrey. Aspergillus oryzae and Aspergillus nidulans var. albus were soil isolates provided by Dr C. H. Dickinson; A. nidulans strain 224 was provided by Professor A. T. Bull (University of Kent, Canterbury); Penicillium chrysogenum wis54-1255 (Righelato et al., 1968) and Penicillium nigricans CMI39767 were from Dr A. Trinci (Department of Microbiology, Queen Elizabeth College, University of London). All other fungi were obtained from the Commonwealth Mycological Institute.

Pseudomonas putida A3.I2 (ATCCI 2633; NCIB9494) was obtained from the National Collection of Industrial Bacteria. Nocardia opaca CA4 was the strain used by Cain, Tranter \& Darrah (1968b) and by Rann (1973).

Media. Fungi were grown on the medium of Cook (1974) supplemented with Io mM-glucose and Io mM$p$-hydroxybenzoate. This medium supported excellent mycelial growth and gave good activities of the cyclase in extracts. Bacteria were grown on the medium of Ornston \& Stanier (1966) with ro mm-p-hydroxybenzoate as inducer.

Growth and maintenance of cultures. All mycelial fungi were maintained by monthly subculture on either $p$-hydroxybenzoate agar or Oxoid potato dextrose agar slopes at $30^{\circ} \mathrm{C}$ unless otherwise stated. Pseudomonas putida and $N$. opaca were similarly maintained on either $p$-hydroxybenzoate agar or Oxoid nutrient agar slopes. Yeasts were maintained on slopes of MYGP medium of Cain et al. (1968a).

Liquid cultures were grown in I 1 of glucose plus $p$-hydroxybenzoate medium in 21 Erlenmeyer flasks incubated at the appropriate temperature on a rotary shaker operated at $140 \mathrm{rev}$. $\mathrm{min}^{-1}$. Inocula for these cultures were grown for 36 to $48 \mathrm{~h}$ in $50 \mathrm{ml}$ of basal medium containing only ro mM-glucose as carbon source; spore inocula were used where possible, but otherwise inocula were mycelial suspensions prepared by homogenizing mycelium cut with a sterile cork-borer from the edge of colonies growing on potato dextrose agar plates. Utilization of the aromatic substrate was monitored spectrophotometrically by measuring the decrease in absorbance at $245 \mathrm{~nm}$ due to $p$-hydroxybenzoate, using a Pye Unicam SP 500 spectrophotometer. Cultures were harvested when the aromatic substrate had decreased by 75 to $80 \%$. This took about $30 \mathrm{~h}$ for rapidly growing species such as Gliocladium deliquescens or Rhodotorula mucilaginosa but up to 4 days for Penicillium commune. At these times the aromatic substrate was being most rapidly consumed and enzyme activities were at a maximum. In shaken cultures, Kernia nitida CMII 51087 grew very slowly and it was therefore grown in stationary culture in $100 \mathrm{ml}$ of glucose liquid medium in I 1 Roux bottles laid flat to increase the surface area. After a firm mycelial mat had formed $\left(6\right.$ to 7 days at $\left.30^{\circ} \mathrm{C}\right)$, the medium was carefully decanted, the mat was rinsed with sterile distilled water, and sterile phosphate buffer, $\mathrm{pH} 6 \cdot 0$, containing ro mM-p-hydroxybenzoate was introduced into the bottle. The refloated mycelial mat began to utilize the aromatic substrate within $36 \mathrm{~h}$ and was harvested when $80 \%$ of this substrate had been consumed.

In some experiments, mycelial fungi were grown with $10 \mathrm{~mm}$-protocatechuate or $2 \mathrm{~mm}$-catechol (sterilized by filtration) instead of $p$-hydroxybenzoate.

Preparation of cell-free extracts. Mycelial fungi were harvested by filtration through muslin and the resulting pads of mycelium were dried between paper towels and stored at $-30^{\circ} \mathrm{C}$ if not required immediately Extracts were prepared by grinding the mycelial pads to a fine powder under liquid nitrogen in a mortar; occasionally acid-washed sand was used as an abrasive. The ground mycelium, after thawing to $5{ }^{\circ} \mathrm{C}$, was extracted with 2 vols potassium phosphate buffer $(0.05 \mathrm{M}, \mathrm{pH} 6.8)$, and the extract was rapidly frozen and thawed twice. Mycelial debris was removed by centrifuging at $38000 \mathrm{~g}$ for $15 \mathrm{~min}$.

Pseudomonas putida, $N$. opaca, R. mucilaginosa and Aur. pullulans were harvested by centrifugation and disrupted ultrasonically in potassium phosphate buffer $(0.05 \mathrm{M}, \mathrm{pH} 6.8)$ as described by Cook \& Cain (1974). Extracts were usually tested immediately but otherwise were stored at $-30^{\circ} \mathrm{C}$ until required. There was a negligible loss of cyclase activity at this temperature over 6 months in extracts of most fungi. However, 
extracts from Gliocladium roseum and $G$. deliquescens were much less stable and were always used immediately.

Enzyme assays. 3-Carboxymuconate cyclase [3-carboxymuconolactone lyase (decyclizing), EC 5.5.I.5], 3-carboxymuconate cycloisomerase [4-carboxymuconolactone lyase (decyclizing), EC 5.5.I.2] and ciscis-muconate cycloisomerase [4-carboxymethyl-4-hydroxyisocrotonolactone lyase (decyclizing), EC 5.5 . I . I ] were assayed according to Cook \& Cain (1974) and Ornston \& Stanier (I966). A unit of activity for these enzymes corresponds to the disappearance of I $\mu \mathrm{mol}$ of 3-carboxymuconate or cis-cis-muconate min $^{-1}$.

Protein was determined by the biuret method of Gornall, Bardawill \& David (1949).

Preparation of antiserum. The immunizing antigen was 3-carboxymuconate cyclase from A. niger L6 [270 units (mg protein) ${ }^{-1}$ ]. The enzyme was purified to homogeneity as described by Thatcher \& Cain (I974a) but with the addition of a final chromatographic treatment on a column $(45 \times 2.5 \mathrm{~cm} \mathrm{diam}$.) of Sepharose 4-B (Pharmacia) equilibrated in potassium phosphate buffer $(0.025 \mathrm{M}, \mathrm{pH} 7 \cdot 6)$. The purified enzyme was dialysed for $60 \mathrm{~h}$ against physiological saline $[0.85 \%(\mathrm{w} / \mathrm{v}) \mathrm{NaCl}]$, diluted in saline to $500 \mu \mathrm{g} \mathrm{ml}^{-1}$ and stored at $-30{ }^{\circ} \mathrm{C}$ as $0.2 \mathrm{ml}$ portions. Each portion contained sufficient enzyme ( $100 \mu \mathrm{g}$ ) for one injection.

Antiserum was prepared in I0-week-old female New Zealand white rabbits; each animal received four intramuscular injections at 3 day intervals followed, after 4 days, by two intravenous injections 3 days apart. The intramuscular injections consisted of enzyme $(100 \mu \mathrm{g})$ diluted to a convenient volume $(0.4 \mathrm{ml})$ with saline and emulsified with an equal volume of Freund's complete adjuvant. Intravenous injections were performed similarly but without adjuvant. Six days after the second intravenous injection the animal was test bled for confirmation of immunological purity by preliminary immunodiffusion experiments, then given a final intravenous injection and bled I week later. The total amount of enzyme administered to each rabbit was thus $700 \mu \mathrm{g}$ (400 $\mu \mathrm{g}$ intramuscularly and $300 \mu \mathrm{g}$ intravenously).

Antiserum against 3-carboxymuconate cycloisomerase from Ps. putida was prepared as described by Stanier et al. (1970) using as the immunizing antigen a partially purified enzyme sample [66 units (mg protein $)^{-1}$, purified to stage 6 of the method of Patel et al. (1973)] provided by Dr L. N. Ornston.

Antibody preparation. IgG immunoglobulin was isolated from sera by repeated precipitation with finely ground solid ammonium sulphate added to $40 \%$ saturation at room temperature. The fourth precipitate was dissolved in borate-buffered saline, exhaustively dialysed against the same buffer and centrifuged (I400 $\mathrm{g}$ for $30 \mathrm{~min}$ ). The final supernatant was adjusted to $\mathrm{I} 6 \mathrm{mg}$ protein $\mathrm{ml}^{-1}$ and stored at $-30{ }^{\circ} \mathrm{C}$ until required (Campbell et al., 1970). Immunoglobulin isolated from antiserum prepared against $\mathrm{A}$. niger L6 3-carboxymuconate cyclase and Ps. putida 3-carboxymuconate cycloisomerase will subsequently be referred to as anti-cyclase IgG and anti-cycloisomerase IgG respectively, and that isolated from normal serum as normal IgG.

Immunodiffusion. This was carried out on microscope slides $(2.5 \times 7.6 \mathrm{~cm})$ using the Ouchterlony doublediffusion technique (Stollar \& Levine, I963). Each slide was evenly coated with $2 \mathrm{ml}$ of agar solution comprising I \% (w/v) Noble agar (Difco) and $0.1 \%(w / v)$ sodium azide in Sorensen's buffer (0.05 M, pH 7.2), and the agar was allowed to harden for $30 \mathrm{~min}$. A punch was used to cut a matrix of six wells $(2 \mathrm{~mm}$ diam.) spaced at a distance of $3 \mathrm{~mm}$ around a centre well and $3 \mathrm{~mm}$ apart.

In all experiments the centre well contained $3 \mu \mathrm{l}$ of purified antibody protein $\left(16 \mathrm{mg} \mathrm{ml}^{-1}\right)$ and each antigen well contained $3 \mu \mathrm{l}$ of pure enzyme or cell-free extract from a test organism. All crude extracts were concentrated by freeze-drying or ultrafiltration and adjusted to a standard activity of 50 units of enzyme per ml of extract. The loaded gels were held in a humidifier at $4{ }^{\circ} \mathrm{C}$ for $36 \mathrm{~h}$ and then examined. Those required for permanent record were washed with several changes of saline to remove unreacted protein, dried at room temperature, stained with acid fuchsin (Campbell et al., 1970) and photographed.

Immunoelectrophoresis. Immunoelectrophoresis was performed on microscope slides as described by Campbell et al. (1970) using a flat-bed electrophoresis apparatus (Shandon Southern Instruments, Camberley, Surrey) at $10 \mathrm{~V} \mathrm{~cm}^{-1}$ applied for $\mathrm{I} \mathrm{h}$. Immediately after electrophoresis a trough was cut in the agar $(60 \times$ I $\mathrm{mm})$, filled with the appropriate IgG $(50 \mu \mathrm{l})$, and the gels were developed, dried, stained and photographed as in a normal immunodiffusion experiment. Occasionally larger glass slides $(12 \times 5.2 \mathrm{~cm})$ were used to compare immunoelectrophoretic behaviour of four or more strains together. Such slides required three or more parallel troughs for antibody administration and 20 to $25 \mathrm{~V} \mathrm{~cm}^{-1}$ applied for 2 to $3 \mathrm{~h}$.

Titration of enzyme with antibody. The affinity of $A$. niger $\mathrm{L} 6$ anti-cyclase IgG for various cycloisomerases or cyclases was quantitatively determined by titrating the enzyme with antibody within the range where the activity decreased linearly with increase in antibody amount. A crude cell-free extract (100 $\mu 1$ ) of the test organism was incubated with dilutions of anti-cyclase IgG in a final volume of $200 \mu$ l. Dilutions of the specific antibody were made with normal IgG ( $6 \mathrm{mg}$ protein $\mathrm{ml}^{-1}$ ). Reaction mixtures were incubated at $37^{\circ} \mathrm{C}$ for $30 \mathrm{~min}$ in $500 \mu \mathrm{l} \mathrm{Beckman}$ microfuge tubes and then further incubated at $4{ }^{\circ} \mathrm{C}$ for $\mathrm{I} 6 \mathrm{~h}$. Any precipitated antigen-antibody complex was removed by centrifuging at $12000 \mathrm{~g}$ for $5 \mathrm{~min}$ (Beckman $\mathrm{I} 52$ microfuge) and the supernatant was assayed for residual 3-carboxymuconate cyclase or cycloisomerase activity. 
The equivalence point, defined as munits of enzyme precipitated per $\mu \mathrm{g}$ of antibody added, was determined from the slope of a plot of residual enzyme activity in the supernatant (units $\mathrm{ml}^{-\mathbf{1}}$ ) against the amount of anti-cyclase IgG used $(\mu \mathrm{g})$. The degree of cross-reactivity of the enzyme in an extract of a specific organism with the antibody prepared against $A$. niger $\mathbf{L} 6$ cyclase was calculated from its observed equivalence point expressed as a percentage of that obtained with the homologous enzyme from $A$. niger $\mathbf{L} 6$.

Modifications required for experiments with the Gliocladium enzyme. Gliocladium roseum grew slowly with poor mycelial yields and enzyme activity whereas $G$. deliquescens grew rapidly and gave extracts with high cyclase activity. Titration of the enzyme in extracts of either species with anti-cyclase IgG or even with normal IgG, prepared in borate-buffered saline, left no residual cyclase activity. This inactivating effect was traced to the saline content of the immunoglobulin preparations (see Results) to which the Gliocladium cyclase was particularly sensitive. Samples of anti-cyclase IgG and normal IgG from the ammonium sulphate precipitation steps were therefore dissolved in borate buffer $(0.05 \mathrm{M}, \mathrm{pH} \mathrm{8.5)}$, rather than in borate-buffered saline, dialysed against the same buffer to remove ammonium sulphate and adjusted to a protein concentration of $16 \mathrm{mg} \mathrm{ml}^{-1}$. Immunotitrations with these saline-free preparations always included positive controls of $A$. niger L6 extract, also prepared without saline, to permit strict comparison with the homologous cyclase.

\section{RESULTS}

Specificity of A. niger $\mathrm{L} 6$ anti-cyclase $\operatorname{Ig} G$ and $P$ s. putida anti-cycloisomerase $\operatorname{Ig} G$

When an electrophoretically pure preparation of 3-carboxymuconate cyclase from $A$. niger L6, and a crude extract of the same fungus grown with $p$-hydroxybenzoate were tested in immunodiffusion experiments with $A$. niger $\mathrm{L} 6$ anti-cyclase $\mathrm{IgG}$, single sharp precipitin lines were formed against both preparations (Fig. I $a$ ); these lines coalesced without spurring indicating identity of the two antigens. A single precipitin line was similarly observed when crude extract from $A$. niger $\mathrm{L} 6$ grown with protocatechuate was used as antigen. The single precipitin lines suggested that the antibody was immunologically pure; this was confirmed by immunoelectrophoresis of the pure enzyme. No precipitin lines were evident against extracts of $A$. niger 16 grown with either catechol or glucose (Fig. I $a$ ), nor were there any non-specific reactions evident when normal IgG was used as antiserum.

The anti-cyclase IgG showed no cross-reaction with purified 3-carboxymuconate cycloisomerase from Ps. putida nor with crude extracts of Ps. putida or $N$. opaca grown with $p$-hydroxybenzoate and concentrated to contain at least 50 units of the enzyme per $\mathrm{ml}$ of extract (Fig. I $d$ ). Conversely, the anti-cycloisomerase IgG derived from Ps. putida gave no cross-reactions on immunodiffusion slides with pure $A$. niger L $6_{3}$-carboxymuconate cyclase or with crude extracts of $A$. niger grown on media which elicited high activities of the cyclase (Fig. I $c$ ). There was likewise no cross-reaction between the anti-cycloisomerase IgG derived from Ps. putida and a crude extract of $N$. opaca grown with $p$-hydroxybenzoate or protocatechuate, confirming the heterologous nature of the cycloisomerases in these two bacteria.

Before using the $A$. niger $\mathrm{L} 6$ anti-cyclase IgG in experiments with other fungi, the identity of the immunological response was confirmed with the Newcastle and Birkbeck strains of $A$. niger where single sharp precipitin lines coalesced perfectly with that given by an extract of induced $A$. niger L6 and showed no spurring (Fig. I $b$ ). Extracts from $A$. niger CMI4555I showed a more diffuse precipitin line but this also coalesced with that formed against the type strain with no evident spurring, indicating homology. No cross-reaction was shown with extracts of the mutant PL 30 grown at $30^{\circ} \mathrm{C}$ (Fig. I $a$ ), suggesting the absence of a protein immunologically related to the active cyclase.

The immunological identity of the cyclases from $A$. niger L6 and the other strains of $A$. niger was confirmed by immunoelectrophoresis of all four $A$. niger strains run concurrently, both separately and as a mixture, on one large glass slide at $\mathrm{pH}$ values $7 \cdot 7,8.5$ and 9.5. Under these conditions all four enzymes moved an identical distance towards the anode at each $\mathrm{pH}$ value during electrophoresis and the arcs of precipitation showed identity of reaction in each case. 

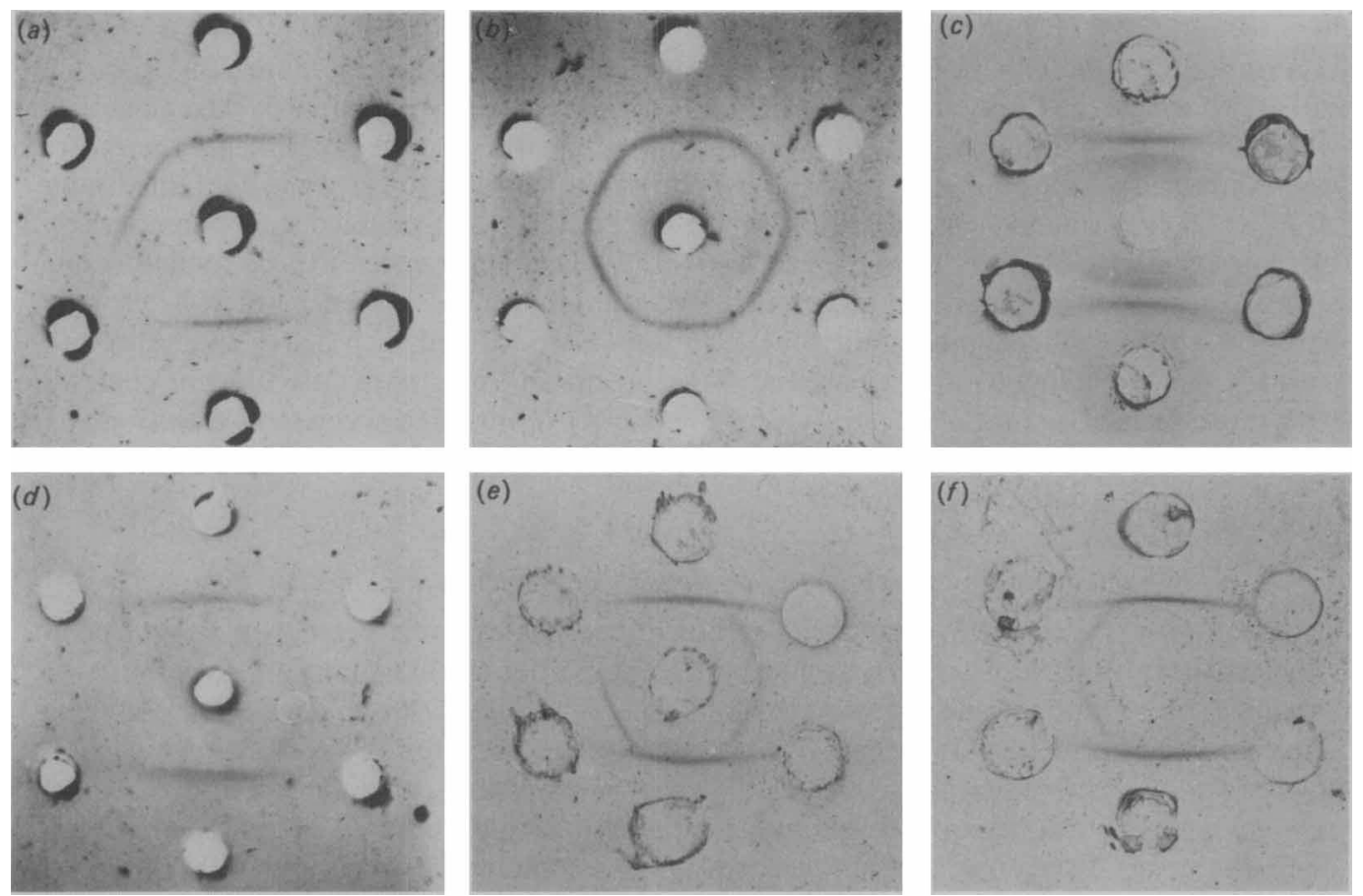

Fig. I. Detection of 3-carboxymuconate cyclase by cross-reaction with purified anti-cyclase IgG to $A$. niger L6. All immunodiffusion experiments were carried out on slides, washed with saline, stained with carbol fuchsin and photographed. Wells are numbered clockwise I to 6 beginning with the uppermost and the centre well contained the antiserum.

(a) Immunological specificity of the purified anti-cyclase IgG. Wells contained: I, pure cyclase from $A$. niger L6; extracts of 2, $A$. niger 16 grown with glucose; 3, A. niger L6 grown with catechol; 4, A. niger L6 grown with protocatechuate; 5, A. niger mutant PL30 (temperaturesensitive cyclase) grown at $30^{\circ} \mathrm{C}$ with $p$-hydroxybenzoate; and $6, A$. niger L6, grown with $p$-hydroxybenzoate.

(b) Immunological identity of $A$. niger strains from various sources. Wells contained: I, pure cyclase from $A$. niger L6; extracts of $2, A$. niger CMI45551; 3, A. niger Birkbeck strain; 4, A. niger L6; $5, A$. niger Newcastle strain; and 6, $A$. niger L6. All crude extracts were derived from cultures grown with $p$-hydroxybenzoate. The centre well contained purified anti-cyclase IgG to $A$. niger L6.

(c) Immunological dissimilarity of 3-carboxymuconate cycloisomerase from Ps. putida and 3-carboxymuconate cyclase from $A$. niger L6 measured against the anti-cycloisomerase IgG to $P s$. putida in the centre well. Wells contained: I, partially purified cycloisomerase from $P s$. putida; 2 and 5, pure cyclase from $A$. niger L6; 3 and 6, extracts of $A$. niger L6 grown with $p$-hydroxybenzoate; and 4 , extract of $P$ s. putida grown with $p$-hydroxybenzoate.

(d) Immunological dissimilarity of 3-carboxymuconate cyclases from $A$. niger 16 and the other fungi and 3-carboxymuconate cycloisomerases from $P s$. putida and $N$. opaca, measured against the anti-cyclase IgG to $A$. niger 16 in the centre well. All cultures were grown with $p$-hydroxybenzoate. Wells contained: I, pure cyclase from $A$. niger L6; extracts of 2, Paecilomyces variotii; 3, Penicillium terrestre; 4, A. niger L6; 5, Ps. putida; and 6, N. opaca.

(e) Immunological cross-reactions between the pure anti-cyclase IgG to $A$. niger $\mathrm{L6}$ (in the centre well) and the cyclase in other species of Aspergillus grown with $p$-hydroxybenzoate. Wells contained: I, pure cyclase from $A$. niger L6; extracts of 2, A. rugulosus; 3, A. nidulans var. albus; 4, A. niger L6; 5, A. terreus; and 6, A. fischeri var. glaber.

( $f$ ) Immunological cross-reactions between the pure anti-cyclase IgG to $A$. niger L6 (in the centre well) and the cyclase in species of Aspergillus and other genera grown with $p$-hydroxybenzoate. Wells contained: I, pure cyclase from $A$. niger $\mathrm{L} 6$; extracts of $2, A$. amstelodami; 3, Trichoderma viride; $4, A$. niger L6; $5, P$. crustosum $\mathrm{P} 6$; and $6, P$. puberulum $\mathrm{B} 3$. 


\section{Immunodiffusion experiments with other species of Aspergillus}

A range of aspergilli (including species known to have ascosporic as well as conidial stages) which utilized $p$-hydroxybenzoate and formed 3-carboxymuconate cyclase (Table I) were examined by immunodiffusion against anti-cyclase IgG. In all experiments the centre well contained $A$. niger $\mathrm{L} 6$ anti-cyclase IgG and the upper and lower wells contained pure $A$. niger $\mathrm{L} 6$ cyclase and $A$. niger crude extract respectively. This enabled direct comparison of cross-reactions between $A$. niger and four other Aspergillus species to be made on one slide. All the Aspergillus species examined gave extracts which showed marked heterology with the $A$. niger L6 enzyme; single precipitin lines were formed with heavy spurs directed towards the heterologous antigen well and the precipitin lines frequently did not coalesce with those formed against $A$. niger cyclase (Fig. I $e, f$ ). With three species ( $A$. amstelodami, $A$. fischeri var. glaber and $A$. fumigatus) from morphological section I (Raper \& Fennell, I965), no cross-reaction was observed.

\section{Immunodiffusion experiments with species of Penicillium and other fungi}

Halsall (197I) established that the 3-carboxymuconate cyclases present in several penicillia had similar molecular weights and kinetic properties to that found in $A$. niger so we extended our immunological examination of the fungal cyclases to include those from selected species of the genus Penicillium and other related genera (Table 3). Species such as $P$. capsulatum, $P$. chrysogenum, $P$. crustosum $\mathrm{P} 6, P$. nigricans, $P$. puberulum $\mathrm{B} 3$ and $P$. rugulosum gave clear cross-reactions by immunodiffusion although marked heterology was evident; there was heavy spurring, diffuse arcs and no coalescence of the precipitin lines with $A$. niger $\mathrm{L} 6$ control extract. (Fig. I $f$ ). Extracts of $P$. commune, $P$. frequentans and $P$. terrestre gave just perceptible but very diffuse precipitin reactions only when concentrated to more than 50 units of cyclase $\mathrm{ml}^{-1}$ (Fig. I $d$ ), while $P$. albicans showed no cross-reaction.

No observable immunodiffusion cross-reactions were obtained using the anti-cyclase IgG with any other fungal extract, even though several of the genera examined have, like Aspergillus and Penicillium, been placed in the Ascomycete families Aspergillaceae (Bessey, 1950), and Trichocomataceae (Malloch \& Cain, 1972) or in the section Phialosporae of the Hyphomycetes (Barron, 1968).

\section{Quantitative titration of the fungal 3-carboxymuconate cyclases with antibody}

The antibody did not appear to bind at or near the catalytic site of the enzyme since no inhibition of total enzyme activity was observed when antibody and enzyme were incubated for up to $\mathrm{I} 2 \mathrm{~h}$ before assaying. The enzyme-antibody complex so formed, however, could be removed from unreacted enzyme by centrifugation. Representative titration curves obtained with extracts from a number of Aspergillus species are shown in Fig. 2.

Determination of their equivalence points (Table 2) confirmed the close identity of the L6, Newcastle and Birkbeck strains indicated previously by immunodiffusion and immunoelectrophoresis. Strain CMI4555I, which had an element of dissimilarity in these tests, still showed over $80 \%$ cross-reaction with $\mathrm{L} 6$, a value well above that found with any other Aspergillus species.

Among the other aspergilli, whether an ascosporic stage is known or not, most species produced a cyclase having 33 to $6 \mathrm{I} \%$ cross-reaction with the anti-cyclase IgG; all of these fell into the broad morphological sections II and III of Raper \& Fennell (1965). Of the remaining four species, all from section I, A. penicilloides (a strict osmophile) was unable to metabolize $p$-hydroxybenzoate but $A$. amstelodami, $A$. fumigatus and $A$. fischeri var. glaber formed an immunologically distinct group with less than $20 \%$ cross-reaction; this degree of dissimilarity may have accounted for the failure of these three species to react in immunodiffusion experiments. 
Table I. Typical activities of 3-carboxymuconate cyclase in extracts of different fungi

The specific activities are those found in extracts of fungi harvested when $80 \%$ of the aromatic substrate ( $p$-hydroxybenzoate or protocatechuate) had been consumed. Datum for $K$. nitida was obtained with extracts of mycelium grown by the replacement technique (see Methods).

Organism

Aspergillus niger L6

$A$. niger (Birkbeck)

$A$. niger (Newcastle)

$A$. niger CMI4555 I

A. amstelodami CMII 7455

A. fischeri var. glaber CMI6I447

A. flavus CMI9I0I96

A. nidulans

$A$. oryzae

A. penicilloides CMI 40816

A. terreus CMII 26254

A. sydowii CMI63904

Penicillium capsulatum CMI40576

$P$. commune CMI398I $2 \mathrm{ii}$

$P$. terrestre CMII I 867

Gliocladium roseum CMI40024ii

$G$. deliquescens CMIIOI 525

Cladosporium resinae CMI 88968

Kernia (Magnusia) nitida CMII 51087

Monascus ruber CMI62570

Paecilomyces variotii CMII08007

Penicilliopsis clavariaeformis CMII60389
Specific activity [units (mg protein) ${ }^{-1}$ ]

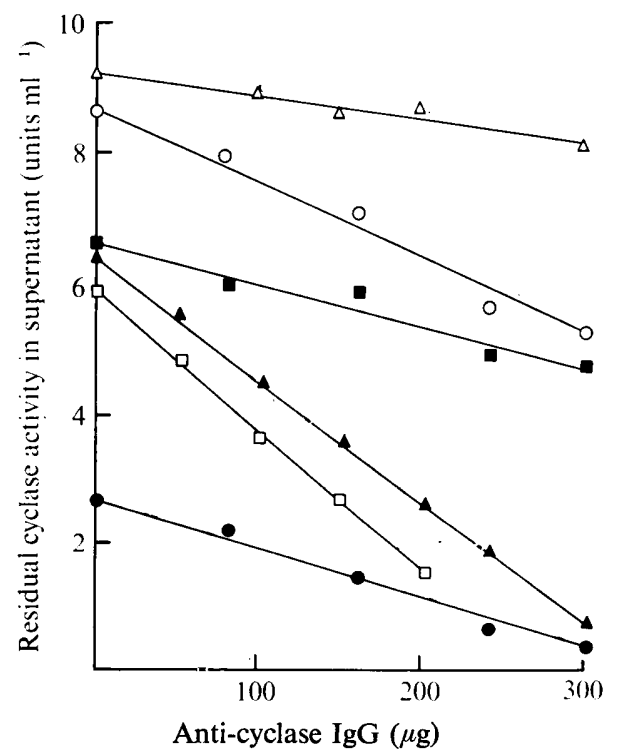

Fig. 2. Quantitative immunotitration of 3-carboxymuconate cyclase in crude extracts of several aspergilli with anti-cyclase IgG. Titrations were carried out as described in Methods using $100 \mu 1$ portions of the appropriate extract and anti-cyclase IgG diluted with normal IgG where necessary. The extracts used were: $\bigcirc$, A. flavus; $\triangle, A$. amstelodami; $\boldsymbol{\square}, A$. oryzae;, , A. versicolor; $\Delta, A$. niger L6; and $\square$, A. niger Birkbeck. 
Table 2. Cross-reactions of $A$. niger 16 anti-cyclase Ig $G$ with 3-carboxymuconate cyclase from Aspergillus species

Equivalence points (munits of 3-carboxymuconate cyclase precipitated per $\mu \mathrm{g}$ of A. niger $\mathbf{L} 6$ anti-cyclase IgG) and the degree of cross-reaction occurring with the enzyme from heterologous sources were determined as described in Methods. The base compositions of fungal DNA are from Storck \& Alexopoulos (1970). Morphology sections are based on the presence of uniseriate and biseriate sterigmata (Raper \& Fennell, 1965; pp. I32-I35).

Organism

$\begin{array}{cc}\text { mol \% GC } & \begin{array}{c}\text { Morphology } \\ \text { in DNA }\end{array} \\ \text { section }\end{array}$

Equivalence
point

$19 \cdot 0$

$22 \cdot 0$

$17 \cdot 2$

$15 \cdot 4$

$3 \cdot 3$

$2 \cdot 5$

0.63

$9 \cdot 0$

I I 6

$6 \cdot 3$

$6 \cdot 9$

$7 \cdot 7$

$6 \cdot 4$

I0.8

$9 \cdot 7$

$8 \cdot 0$

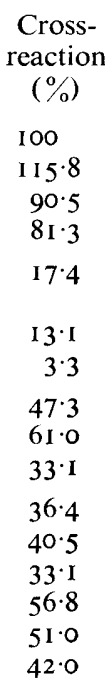

Most of the penicillia examined (Table 3) were species of the Asymmetrica and Biverticillata sections of the genus, which, with the exception of $P$. commune, formed an immunologically compact group whose cyclases all showed 37 to $47 \%$ cross-reaction with the anticyclase IgG. Two species of the morphologically distinct Monoverticillata subgroup, $P$. capsulatum and $P$. frequentans, were also immunologically distinct with $27 \%$ and $28 \%$ cross-reacting cyclases, respectively, while $P$. albicans, a member of the Polyverticillata subgroup with many Scopulariopsis-like features (Raper \& Thom, I949) produced, like Scopulariopsis candida, a cyclase which showed less than $4 \%$ cross-reaction.

Among other genera examined, those acknowledged on morphological and cultural criteria as having some relationship with Aspergillus and Penicillium all gave cyclases with a detectable cross-reaction with the anti-cyclase IgG (Table 3). In contrast, extracts of the Basidiomycetes Schizophyllum commune and Rhodotorula mucilaginosa (Banno, 1967), of Trichoderma viride and Aureobasidium pullulans and of the bacteria Ps. putida and $N$. opaca, showed no cross-reaction with the anti-cyclase IgG in these experiments.

\section{Saline-sensitive 3-carboxymuconate cyclase from Gliocladium}

Immunotitration of extracts of $G$. deliquescens and $G$. roseum with $A$. niger $L 6$ anti-cyclase IgG led to complete loss of enzyme activity in the supernatants; a similar effect was observed when normal IgG was used, even when greatly diluted in borate-buffered saline (containing I $45 \mathrm{mM}-\mathrm{NaCl}$ ). As polyvalent anions inhibit some fungal cyclases (Thatcher \& Cain, 1975) we suspected that borate was inhibiting the cyclase but eventually found that, unlike the cyclase of $A$. niger, the enzymes from $G$. deliquescens and $G$. roseum were sensitive to brief exposure to $\mathrm{NaCl}$ or $\mathrm{KCl}, \mathrm{I} \cdot 45 \mathrm{mM}$ and $0.145 \mathrm{~mm}-\mathrm{NaCl}$ causing $90.7 \%$ and $37.6 \%$ inhibition, respectively, of the cyclase. When preparations of both anti-cyclase IgG and normal IgG were made in borate buffer (see Methods) rather than in borate-buffered saline, normal 
Table 3. Cross-reactions of $A$. niger $\mathrm{L} 6$ anti-cyclase IgG with 3-carboxymuconate cyclase from species of Penicillium and other genera

Conditions and calculations are as described in the legend to Table 2. The morphology sections used for the taxonomic classification of the penicillia are those of Raper \& Thom (I949). The equivalence point of $A$. niger $\mathrm{L} 6$, titrated with anti-cyclase IgG prepared in borate-buffered saline, was $19 \cdot 0$.

\section{Organism}

\section{A. Penicillium frequentans} CMI28043

P. capsulatum CMI40576

$P$. nigricans CM139767

$P$. commune CMI3981 $2 \mathrm{ii}$

$P$. chrysogenum

$P$. crustosum $\mathrm{P6}$, CMII9I672

$P$. puberulum B3

P. terrestre CMII 11867

$P$. rugulosum CMII 34323

$P$. albicans CMI63215

B. Monascus ruber CMI62570

Paecilomyces variotii CMI 108007

Penicilliopsis clavariaeformis CMII 60389

Kernia (Magnusia) nitida CMII 51087

Scopulariopsis candida CMII 29578

Cladosporium resinae CMI88968

Trichoderma viride

Aureobasidium pullulans

C. Rhodotorula mucilaginosa Schizophyllum commune

D. Nocardia opaca CA4 Pseudomonas putida A3.1 2
Morphology section and subsection

\section{Monoverticillata}

Monoverticillata

Asymmetrica-Divaricata

Asymmetrica-Lanata

Asymmetrica-Velutina

Asymmetrica-Fasciculata Asymmetrica-Fasciculata Asymmetrica-Funiculosa

Biverticillata-Symmetrica

Polyverticillata

$$
\begin{aligned}
& \text { mol \% } \\
& \text { GC in } \\
& \text { DNA }
\end{aligned}
$$$$
\begin{aligned}
& \text { Equivalence } \\
& \text { point }
\end{aligned}
$$

Cross-

\begin{tabular}{|c|c|c|}
\hline $5 \mathrm{I}$ & $5 \cdot 3$ & 28 \\
\hline $5 I \cdot 5-52$ & $5 \cdot 2$ & 27 \\
\hline- & $8 \cdot 0$ & 42 \\
\hline- & $2 \cdot 7$ & 14.2 \\
\hline $5 \mathrm{I}-54$ & $8 \cdot 3$ & $43 \cdot 6$ \\
\hline - & $7 \cdot 6$ & 40 \\
\hline - & $8 \cdot 9$ & 47 \\
\hline- & $7 \cdot 1$ & $37 \cdot 3$ \\
\hline $50 \cdot 5-55$ & $9 \cdot I$ & $47 \cdot 8$ \\
\hline- & 0.66 & 3.5 \\
\hline- & $2 \cdot 63$ & 13.8 \\
\hline $51 \cdot 5$ & $I \cdot 75$ & 9.2 \\
\hline- & $1 \cdot 38$ & $7 \cdot 3$ \\
\hline- & $1 \cdot 38$ & $7 \cdot 3$ \\
\hline 50 & 0.75 & 3.9 \\
\hline 54 & 0.83 & 4.4 \\
\hline $49 \cdot 5$ & 0 & 0 \\
\hline $5 I \cdot 5$ & 0 & 0 \\
\hline $6 I-63$ & 0 & 0 \\
\hline $57-61$ & 0 & 0 \\
\hline 62 & 0 & 0 \\
\hline $62 \cdot 5$ & 0 & 0 \\
\hline
\end{tabular}
reaction $(\%)$

titration curves were obtained with both the Gliocladium species and with $A$. niger L6. The equivalence point for $A$. niger L6 extracts titrated with borate-buffered anti-cyclase IgG was 17.4 , insignificantly different from values obtained previously in borate-buffered saline (Table 2). We therefore regard the results obtained for $G$. deliquescens (equivalence point $\mathrm{I} \cdot 08 ; 6 \cdot 2 \%$ cross-reaction) and $G$. roseum (equivalence point $0 \cdot 23, \mathrm{I} \cdot 3 \%$ cross-reaction) as valid comparisons.

\section{DISCUSSION}

Fungal taxonomists have traditionally relied upon morphological characters, particularly the structure of sexual fruiting bodies, to establish their classifications. Indeed some have suggested that 'only morphological characters should be used to delimit species and all higher categories' (Snyder \& Tousson, 1965), despite the fact that many of these features are based on subjective descriptions. This is particularly true of most of the genera examined in this paper, namely the form-genera within the Hyphomycetes (Barron, 1968; Kendrick \& Carmichael, 197I) and the Plectomycetes which Fennell (I973) admitted was an 'unnatural class'.

An extensive analysis of the DNA base composition of fungi by Storck \& Alexopoulos 
(1970) showed that the whole subdivision Ascomycotina was encompassed within the range 48.5 to $60.0 \mathrm{~mol} \%$ GC. Indeed, most species of the genera Aspergillus (sensu Raper \& Fennell, 1965) and Penicillium (sensu Raper \& Thom, 1949) (which include those ascogenic species now classified as Eurotium, Emericella, Sartorya, Chaetosartorya, Talaromyces, Eupenicillium and Byssochlamys) have mol \% GC contents of $53.5 \pm 0.4$ S.E.M. (range 48 to $6 \mathrm{I}$ ) and $5 \mathrm{I} \cdot 5 \pm 0 \cdot 24$ S.E.M. (range 47 to 60 ) respectively, so clearly cannot be distinguished by this method. For genetically based taxonomic relationships, DNA base pairing will probably ultimately provide the best approach (De Ley, I968), but this has been little exploited by mycologists (Dutta \& Ojha, 1972).

In the absence of distinct taxa based on nucleic acid composition, Wilson \& Kaplan (I964) and Valen (1973) suggested that relationships between organisms could be revealed by comparing the structure of their enzymes since the amino-acid sequence of each enzyme would be a direct translation of the nucleotide sequence in a segment of the genetic material. Of the numerous protein analysis methods available, mycologists have made comparatively little use of serology as a taxonomic aid. Nowhere, for example, in monographs on the taxonomy of Aspergillus (Raper \& Fennell, 1965) and Penicillium (Raper \& Thom, 1949), is reference made to a single serological investigation, yet Mez (1929), with extraordinary foresight, was using serology to establish likely relationships between the Phycomycetes and Ascomycetes 25 years before the link between DNA and proteins was finally resolved. Even where the method has been tried, crude preparations of intact or ruptured spores and mycelia have been used as the antigen (Madhosingh, I964; Amos \& Burrell, 1967; Morton \& Dukes, 1967; Biguet, Tran van Ky \& Andrieu, 1966; Andrieu et al., 1969), though the necessity for antibody, raised against a pure protein, was recognized by Imamoto, Yamane \& Sueoka (1965) for quantitative comparison of homologous enzymes in crude extracts of related species.

The structural features of the proteins which determine why the bacterial cycloisomerase and fungal cyclase act on the same substrate yet produce isomeric products are still far from clear but serological investigations on mutant forms of the enzyme and on wild-type enzymes from related genera provide one insight into the problem. Aspergillus niger L6 was chosen for study because of its ubiquity (Raper \& Fennell, 1965), its ability to grow rapidly upon several aromatic compounds (Cain et al., I $968 a$ ), the availability of the homogeneous cyclase purified from it (Thatcher \& Cain, I974a) and the existence of several mutants with modified abilities to catabolize aromatic compounds (E. F. Ahlquist, unpublished results). We have confirmed the immunological dissimilarity of the $A$. niger L6 cyclase and the cycloisomerase from Ps. putida originally suspected from considerable differences in their aminoacid composition and quaternary structure (Patel et al., I973; Thatcher \& Cain, I974b). The 3-carboxymuconate cyclase and the cis-cis-muconate cycloisomerase of $A$. niger $\mathbf{L} 6$ (the latter is present in extracts of the fungus grown with $2 \mathrm{~mm}$-catechol) were also serologically distinct - a feature noted in Ps. putida and Acinetobacter calcoaceticus (Patel et al., I973; Stanier et al., 1970).

\section{Cross-reactions within Aspergillus}

Within the genus Aspergillus (including ascosporic species), four strains of $A$. niger were immunologically identical although one, the Birkbeck strain, was culturally quite distinct in producing yellow mycelium and secreting a yellow pigment in liquid media. The species with the closest immunological relationship to $A$. niger L6 was $A$. flavus (Table 2); these two species are regularly isolated from soil, both produce sclerotia, share the ability to attack many naturally-occurring aromatic compounds (Westlake \& Simpson, 196I; Simpson, Narasimhachari \& Westlake, 1963) and fall into section II of the classification of Raper \& Fennell (1965), having biseriate or occasionally uniseriate sterigmata. Aspergillus candidus, also in section II, differs little from $A$. niger except for the absence of conidial pigmentation and roughening and showed considerable homology in its cyclase. 
Many of the most widely distributed and well recognized species, all with strictly biseriate sterigmata, belong to section III (Raper \& Fennell, I965). All had cyclases which fell within the range 33 to $57 \%$ cross-reaction with the anti-cyclase IgG but since this range also spans values obtained with some section II species, our results suggest that aspergilli which at any time show biseriate sterigmata should be classified together and that sections II and III could be merged. In contrast, section I species, all of which have strictly uniseriate sterigmata, showed less than $20 \%$ cross-reacting cyclases. They are therefore readily distinguishable morphologically and serologically from the other aspergilli. Species of this section also show osmophilic and thermotolerant properties which enable them to colonize substrates with low moisture content. Aspergillus penicilloides required such high sucrose concentrations for growth in liquid media that we were unable to induce aromatic degradation (Table I).

\section{Cross-reaction with other genera}

Among bacterial cycloisomerases that have been examined serologically, interspecies dissimilarity was extensive (Stanier, 1967; Stanier et al., 1970) and intergeneric cross-reaction absent (Patel et al., 1973; Patel \& Ornston, 1976). However, both immunodiffusion and quantitative precipitin methods revealed that most species of the Asymmetrica and Biverticillata-Symmetrica sections of Penicillium gave cyclases with 40 to $50 \%$ crossreaction (Table 3 ) and the two Monoverticillata species, $P$. capsulatum and $P$. frequentans produced cyclases with 27 to $28 \%$ cross-reaction and so comprise serologically distinct groups. Raper \& Thom (1949) recognized the uncertain taxonomic position of $P$. albicans when they placed it in their Polyverticillata section and drew attention to its Scopulariopsislike character. This aberrant relationship was confirmed serologically by the similar weak cross-reacting pattern of the cyclases from $P$. albicans and Scopulariopsis candida (Table 3).

In addition to Aspergillus and Penicillium, Bessey (1950) included in his family Aspergillaceae the perithecial-forming genera Monascus, Lilliputia (conidial form Gliocladium), Penicilliopsis and Magnusia (Kernia). Raper \& Thom (1949) believed Gliocladium to be closely related to Penicillium with Paecilomyces and Scopulariopsis further removed genetically. The close relationship of Paecilomyces and Penicillium was emphasized by Brown \& Smith (1957) but Paecilomyces-like and Penicillium-like conidial stages have both been described for the thermotolerant, ascosporic genus Talaromyces (Stolk \& Samson, 1971). Malloch \& Cain (1972) pointed out that the name Aspergillaceae should apply only to Fungi Imperfecti and validated the family Trichocomataceae to include those Ascomycetes with Aspergillus, Penicillium, Paecilomyces and Gliocladium conidial states. Fennell (1973) nevertheless regarded this family as an artificial grouping and Barron (I968) placed these four form-genera and Trichoderma in his Phialosporae division of the soil-borne Hyphomycetes. Whether or not ascocarp or conidial morphology is regarded as the more important taxonomic feature, our results confirm that these genera (which incidentally have similar DNA base ratios) are, some albeit distantly, serologically related to Aspergillus. In contrast, the basidiomycete fungi Schizophyllum commune and Rhodotorula mucilaginosa have a much higher GC content (around $60 \mathrm{~mol} \%$ ) and their cyclases show no serological relationship to those of $A$. niger; the cyclases also differ substantially in their quaternary structure (R. B. Cain, A. Columbi \& B. A. Halsall, unpublished results).

Therefore, within the Aspergillaceae (sensu Bessey, 1950), the results of our serological study confirm generic relationships and in Aspergillus and Penicillium broadly conform with intrageneric subdivisions based on morphological characters, The future use of the more sensitive micro-complement fixation technique (Kaplan, 1965) with many more species may better delimit intrageneric subdivisions and even species. We believe the use of 3-carboxymuconate cyclase as the antigen is justified because it is a uniquely fungal enzyme, unknown in prokaryotes or other eukaryotes, and has been found in over 40 
genera of Phycomycetes, Ascomycetes, Basidiomycetes and Fungi Imperfecti (Cain et al., I968a; Halsall, Darrah \& Cain, I969). In the majority of these genera, the enzyme is stable for months in frozen extracts and raises good antibody titres.

The homology of the cyclase in fungal genera which, though similar in DNA base ratios, are distinguishable morphologically, implies considerable conservation of its protein structure. Such conservation is further supported by similar molecular weights, sub-unit sizes, kinetic constants, activation energies and $\mathrm{pH}$ optima of the cyclases from different genera (Halsall, 197I) and is perhaps not unexpected in an enzyme with strict specificity (Thatcher \& Cain, 1975) for a substrate which can be derived from relatively few precursors. Fungi regulate the protocatechuate branch of the 3-oxoadipate pathway, which includes the cyclase, by substrate induction with either $p$-hydroxybenzoate or protocatechuate; the cyclase is always co-ordinately induced with 3-carboxymuconolactone hydrolase which removes the unique fungal metabolic product of cyclase action (Halsall, Darrah \& Cain, 1969; Halsall, 1971; Cook \& Cain, 1974; Huber et al., 1975; E. F. Ahlquist and R. B. Cain, unpublished results). In soil such inducers probably derive from lignin (Henderson, I96I), flavonoids or alicyclic compounds like shikimate and quinate occurring in the litter from decomposing plant remains. Since many of the fungi examined in this paper occur in soil and plant litter (see Griffin, 1972; Dickinson \& Pugh, 1974), the aromatic catabolic pathway which they have in common may itself have provided a selective force favouring evolution of the structure of a key catalytic protein and its conservation in genera that are quite distinct morphologically.

This study was supported by a grant from the Science Research Council (B/RG/3509) to R. B. Cain which is gratefully acknowledged.

\section{REFERENCES}

Andrieu, S., Biguet, J., Dujardin, L. \& Vaucelle, T. (1969). Antigenic study of agents causing severe mycoses by comparative analysis of culture media. Mycopathologia et mycologia applicata 39, 97108.

Amos, R. E. \& Burrell, R. G. (I 967). Serological differentiation in Ceratocystis. Phytopathology 5 , 32-34.

BANNO, I. (1967). Studies on the sexuality of Rhodotorula. Journal of General and Applied Microbiology 13, 167-196.

BARRON, G. L. (1968). The Genera of the Hyphomycetes from Soil. Baltimore: William \& Wilkins.

Bessey, E. A. (1950). Morphology and Taxonomy of Fungi, p. 356. London: Constable.

Biguet, J., Tran van Ky, P. \& Andrieu, S. (I966). Immunoelectrophoretic analysis of fungal antigens. Taxonomic and diagnostic significance. Bulletin de la Société de pharmacie de Nancy 71, 6-25.

Brown, A. H. S. \& Smith, G. (1957). The genus Paecilomyces Bainier and its perfect stage. Transactions of the British Mycological Society 40, 17-59.

CAin, R. B., Bilton, R. F. \& Darrah, J. A. (1968a). The metabolism of aromatic acids by microorganisms. Metabolic pathways in the fungi. Biochemical Journal 108, 797-828.

Cain, R. B., Tranter, E. K. \& Darrah, J. A. $(1968 b)$. The utilization of some halogenated aromatic acids by Nocardia. Oxidation and metabolism. Biochemical Journal 106, 2 I I-227.

Campbell, D. H., Garvey, J. S., Cremer, N. E. \& SUSDORF, D. H. (1970). Methods in Immunology, 2nd edn. New York: W. A. Benjamin.

CoOK, K. A. (1974). Regulation of aromatic metabolism in fungi: selection of mutants of the yeast Rhodotorula mucilaginosa with nystatin. Journal of General Microbiology 85, 29-36.

CoOK, K. A. \& CAIN, R. B. (1974). Regulation of aromatic metabolism in the fungi: metabolic control of the 3-oxoadipate pathway in the yeast Rhodotorula mucilaginosa. Journal of General Microbiology 85, 37-50.

DE LEY, J. (I968). DNA base composition and hybridization in the taxonomy of phytopathogenic bacteria. Annual Review of Phytopathology 6, 65-90.

Dickinson, C. H. \& Pugh, G. F. J. (1974). Biology of Plant Litter Decomposition, vol. I. London: Academic Press.

DutTA, S. K. \& OJнA, M. (1972). Relatedness between major taxonomic groups of fungi based on measurement of DNA nucleotide sequence homology. Molecular and General Genetics Ir4, 232-240.

FenNell, D. I. (1973). Plectomycetes; Eurotiales. In The Fungi, vol. IV A, pp. 45-68. Edited by G. C. Ainsworth, F. K. Sparrow and A. S. Sussman. London: Academic Press. 
Gornall, A. G., Bardawill, C. J. \& David, M. M. (1949). Determination of serum proteins by means of the Biuret reaction. Journal of Biological Chemistry 177, 75I-766.

Griffin, D. M. (1972). Ecology of Soil Fungi, pp. 29-43. London: Chapman and Hall.

Gross, S. R., Gafford, R. D. \& Tatum, E. L. (1956). The metabolism of protocatechuic acid by Neurospora. Journal of Biological Chemistry 219, $75 \mathrm{I}-795$.

Halsall, B. E. (1971). Metabolism of aromaticring compounds and its regulation in fungi. Ph.D. thesis, University of Newcastle upon Tyne.

Halsall, B. E., Darrah, J. A. \& Cain, R. B. (1969). The regulation of enzymes of aromaticring fission in fungi: organisms using both catechol and protocatechuate pathways. Biochemical Journal n14, $75 \mathrm{P}$.

Henderson, M. E. K. (1961). The metabolism of aromatic compounds related to lignin by some Hyphomycetes and yeast-like fungi of soil. Journal of General Microbiology 26, I 55-165.

Huber, T. J., Street, J. R., Bull, A. T., Cook, K. A. \& CAIN, R. B. (1975). Aromatic metabolism in the fungi. Growth of Rhodotorula mucilaginosa in $p$-hydroxybenzoate-limited chemostats and the effect of growth rate on the synthesis of enzymes of the 3-oxoadipate pathway. Archives of Microbiology 102, 139-144.

Imamoto, F., Yamane, T. \& SueokA, N. (1965). Existence of two phenylalanyl-sRNA synthetases in Neurospora crassa. Proceedings of the National Academy of Sciences of the United States of America 53, 1456-1462.

I.U.P.A.C.-I.U.B. Commission on Biochemical Nomenclature (1972). Enzyme Nomenclature. Amsterdam: Elsevier.

KAPLAN, N. O. (1965). Evolution of dehydrogenases. In Evolving Genes and Proteins, pp. 243-277. Edited by V. Bryson and H. J. Vogel. New York: Academic Press.

KENDRICK, W. B. \& Carmichael, J. W. (I97I). Hyphomycetes. In The Fungi, vol. IV A, pp. 323-503. Edited by G. C. Ainsworth, F. K. Sparrow and A. S. Sussman. London: Academic Press.

Madhosingh, C. (1964). A serological comparison of three Fusarium species. Canadian Journal of Botany 42, I I 43-I 47.

Malloch, D. \& CaIn, R. F. (1972). The Trichocomataceae: Ascomycetes with Aspergillus, Paecilomyces and Penicillium imperfect states. Canadian Journal of Botany 50, 2613-2628.

MEZ, C. (1929). Versuch einer Stammesgeschichte des Pilzreichs. Schriften der Königsberger gelehrten Gesellschaft 6, I-58.

Morton, D. J. \& Dukes, P. D. (1967). Serological differentiation of Pythium aphanidermatum from Phytophthora parasitica var. nicotianae and Phytophthora parasitica. Nature, London 213, 923-925.

ORnston, L. N. \& Stanier, R. Y. (I966). The conversion of catechol and protocatechuate to $\beta$ ketoadipate by Pseudomonas putida. I. Biochemistry. Journal of Biological Chemistry 241, 37763786.
Patel, R. N. \& Ornston, L. N. (1976). Immunological comparison of enzymes of the $\beta$-ketoadipate pathway. Archives of Microbiology 110, 27-36.

Patel, R. N., Meagher, R. B. \& Ornston, L. N. (1973). Relationships among enzymes of the $\beta$ ketoadipate pathway. II. Properties of crystalline $\beta$-carboxy-cis,cis-muconate-lactonizing enzyme from Pseudomonas putida. Biochemistry 12, 353 I3537.

RANN, D. L. (1973). Regulation of the 3-oxoadipate pathway in the genus Nocardia. Ph.D. thesis, University of Newcastle upon Tyne.

Raper, K. B. \& Fennell, D. I. (1965). The genus Aspergillus. Baltimore: Williams \& Wilkins.

RAPer, K. B. \& THом, C. (1949). A Manual of the Penicillia. Baltimore: Williams \& Wilkins.

Righelato, R. C., Trinci, A. P. J., Pirt, S. J. \& Peat, A. (1968). The influence of maintenance energy and growth rate on the metabolic activity, morphology and conidiation of Penicillium chrysogenum. Journal of General Microbiology 50, 399-412.

Simpson, F. J., Narasimhachari, N. \& Westlake, D. W. S. (1963). Degradation of rutin in Aspergillus flavus. The carbon monoxide producing system. Canadian Journal of Microbiology 9, 1 5-25.

SNyder, W. C. \& Tousson, T. A. (I965). Current status of taxonomy in Fusarium species and their perfect stages. Phytopathology 55, 833-837.

StANIER, R. Y. (I967). Biochemical and immunological studies on the evolution of a metabolic pathway. In Chemotaxonomy and Serotaxonomy, pp. 20I-225. Edited by J. G. Hawkes. Systematics Association Special Volume 2. London: Academic Press.

Stanier, R. Y. \& Ornston, L. N. (1973). The $\beta$ ketoadipate pathway. In Advances in Microbial Physiology, vol. 9, pp. 89-15I. Edited by A. H. Rose and D. W. Tempest. London: Academic Press.

Stanier, R. Y., Wachter, D., Gasser, C. \& Wilson, A. C. (1970). Comparative immunological studies of two Pseudomonas enzymes. Journal of Bacteriology ro2, 35 I-362.

Stolk, A. C. \& Samson, K. A. (1971). Studies on Talaromyces and related genera. I. Hamigera gen. nov. and Byssochlamys. Persoonia (Leiden) 6, 34 I-357.

Stollar, D. \& Levine, L. (1963). Two-dimensional immunodiffusion. Methods in Enzymology VI, 848-854.

Storck, R. \& Alexopoulos, C. J. (1970). Deoxyribonucleic acid of fungi. Bacteriological Reviews 34, I 26-I 54 .

Thatcher, D. R. \& CAIN, R. B. (I974a). Metabolism of aromatic compounds by fungi. I. Purification and physical properties of 3carboxy-cis, cis-muconate cyclase from Aspergillus niger. European Journal of Biochemistry 48, 549556.

Thatcher, D. R. \& Cain, R. B. (1974b). Metabolism of aromatic compounds by fungi. 2 . Subunit structure of 3-carboxy-cis,cis-muconate cyclase of Aspergillus niger. European Journal of Biochemistry 48, 557-562. 
ThatCher, D. R. \& CAIN, R. B. (1975). Metabolism of aromatic compounds by fungi. Kinetic properties and mechanism of 3-carboxy-cis, cis-muconate cyclase from Aspergillus niger. European Journal of Biochemistry 56, I93-209.

VALEN, L. VAN (1973). Are categories in different phyla comparable? Taxon 22, 333-373.
Westlake, D. W. S. \& Simpson, F. J. (I96I). Degradation of rutin by Aspergillus flavus. Factors affecting production of the enzyme system. Canadian Journal of Microbiology 7, 33-44.

Wilson, A. C. \& Kaplan, N. O. (I964). Enzyme structure in relation to taxonomy. In Taxonomic Biochemistry and Serology, pp. 321-346. Edited by C. A. Leone. New York: Ronald Press. 